
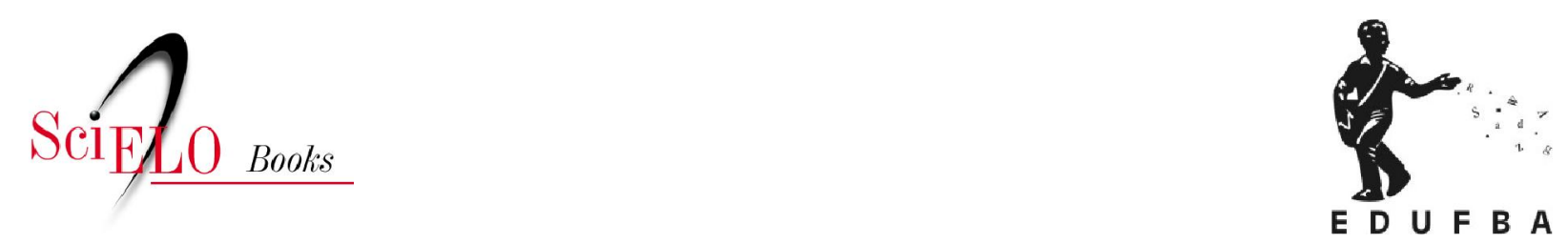

\title{
Manual básico para atendimento ambulatorial em nutrição
}

\author{
Nilze Barreto Villela \\ Raquel Rocha \\ (orgs.)
}

VILLELA, NB., and ROCHA, R., orgs. Manual básico para atendimento ambulatorial em nutrição [online]. 2nd ed. rev. and enl. Salvador: EDUFBA, 2008. 120 p. ISBN 978-85-232-0899-8. Available from SciELO Books $<$ http://books.scielo.org $>$.

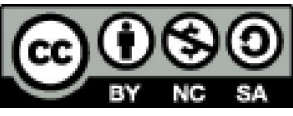

All the contents of this work, except where otherwise noted, is licensed under a Creative Commons Attribution-Non Commercial-ShareAlike 3.0 Unported.

Todo o conteúdo deste trabalho, exceto quando houver ressalva, é publicado sob a licença Creative Commons Atribuição Uso Não Comercial - Partilha nos Mesmos Termos 3.0 Não adaptada.

Todo el contenido de esta obra, excepto donde se indique lo contrario, está bajo licencia de la licencia Creative Commons Reconocimento-NoComercial-CompartirIgual 3.0 Unported. 


\title{
Manual Básico
}

\author{
para \\ Atendimento \\ Ambulatorial em \\ Nutrição
}




\section{㿿 \\ UNIVERSIDADE FEDERAL DA BAHIA \\ Reitor \\ Naomar Monteiro de Almeida Filho \\ Vice-Reitor \\ Francisco Mesquita}

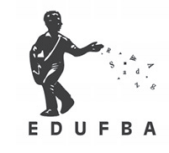

EDITORA DA UNIVERSIDADE FEDERAL DA BAHIA

Diretora

Flávia Goullart Mota Garcia Rosa

Conselho Editorial

Ângelo Szaniecki Perret Serpa

Caiuby Alves da Costa

Charbel Ninõ El-Hani

Dante Eustachio Lucchesi Ramacciotti

José Teixeira Cavalcante Filho

Maria do Carmo Soares Freitas

Conselheiros Suplentes

Alberto Brum Novaes

Antônio Fernando Guerreiro de Freitas

Armindo Jorge de Carvalho Bião

Evelina de Carvalho Sá Hoisel

Cleise Furtado Mendes

Maria Vidal de Negreiros Camargo 


\title{
Manual Básico
}

\section{para \\ Atendimento \\ Ambulatorial em \\ Nutrição}

\author{
Nilze Barreto Villela \\ Prof. Adjunta, Escola de Nutrição, UFBA \\ Raquel Rocha \\ Prof. Assistente, Escola de Nutrição, UFBA
}

$2^{\mathrm{a}}$ edição

revista e ampliada

EDUFBA

Salvador 2008 
๑2001 by Nilze Barreto Villela e Raquel Rocha.

Direitos para a língua portuguesa adquiridos pela Editora da Universidade Federal da Bahia. Feito o depósito legal.

Capa e projeto gráfico: Angela Garcia Rosa

Editoração eletrônica: Genilson Lima

Tratamento de imagens: Rodrigo Schlabitz

Foto da capa: Danilo Watanabe

Revisão: das autoras

Biblioteca Central Reitor Macêdo Costa - UFBA

V735 Villela, Nilze Barreto.

Manual básico para atendimento ambulatorial em nutrição / Nilze

Barreto Villela, Raquel Rocha. - 2. ed.. - Salvador : EDUFBA, 2008.

$120 \mathrm{p}$.

Inclui anexo.

ISBN 978-85-232-0497-6

1. Nutrição - Manuais, guias, etc. 2. Hábitos alimentares.

3. Alimentação - Manuais, guias, etc. 4. Aconselhamento em nutrição.

I. Rocha, Raquel. II. Título.

CDD - 303.6

EDUFBA

Rua Barão de Geremoabo, s/n

Campus de Ondina, Salvador-BA

CEP 40170-290

Tel/fax: (71) 3283-6164

www.edufba.ufba.br

edufba@ufba.br 


\section{APRESENTAÇÃO}

$\mathbf{0}$ conhecimento que emana das ciências da Alimentação e Nutrição apesar dos avanços tecnológicos e dos princípios que norteiam a globalização, ainda permanece restrito a um grupo específico da população brasileira, compreendendo-se a grande estiagem que permeou por muitos anos entre os traços culturais, o acreditar na ciência, a hegemonia de outras áreas da saúde que sufocou o expandir da Alimentação/Nutrição, e também a falta de estrutura e o querer político de assumir graves problemas da saúde sanáveis através destas Ciências, independente de raça, credo, ou, situação econômico social.

A ausência de um trabalho educativo, somado aos hábitos e tabus alimentares, tendo por base informações distorcidas pelos mais variados interesses, levam o indivíduo ao desequilíbrio nutricional, o mesmo acontecendo quando da ingestão excessiva de alguns nutrientes em detrimento de outros, ou, ainda a deficiência da oferta dos nutrientes, elementos vitais para a saúde humana.

No nosso quotidiano, temos relatos dos mais variados, que fortalecem nossa proposta, nos norteando para desenvolver ações educativas.

Toda experiência acumulada apontou resultados que nos encorajaram a desenvolver o presente trabalho, na forma de Manual, elaborado com a finalidade de proporcionar melhoria 
do atendimento, auxiliando não somente o entendimento das instruções fornecidas aos pacientes ou seu cuidador, mas aos discentes - profissionais em formação - e outros profissionais da Área de Saúde, que atuam no Ambulatório de Nutrição do Pavilhão Professor Francisco Magalhães Neto. Contudo as orientações aqui contidas, não substituem o atendimento nutricional individualizado, onde o nutricionista tem todo um proceder científico pautado nas necessidades nutricionais de cada indivíduo, dentro das características específicas do quadro patológico apresentado, e, das condições básicas de vida do assistido.

Colocamos ao seu dispor, como usuário, este Manual, na expectativa de que possa utiliza-lo para servir aos interesses da sociedade, representada por aqueles que buscam o atendimento em Ambulatórios de Nutrição, de forma adequada e segura, dentro de suas reais condições. 


\title{
SUMÁRIO
}

\author{
1 \\ RECOMENDAÇÕES NUTRICIONAIS \\ Para vida saudável 13 \\ Adolescentes 15 \\ Terceira Idade 17 \\ Atleta 19 \\ 2 \\ TERAPÊUTICA NUTRICIONAL \\ Anemia falciforme 23 \\ Anemia ferropriva 24 \\ Anorexia nervosa 25 \\ Cardiopatias 27 \\ Cefaléia 29 \\ Cirurgia bariátrica 31 \\ Colostomia 34 \\ Diabetes mellitus 36 \\ Diarréia 39 \\ Dislipidemia 41 \\ Doença celíaca 43 \\ Doença diverticular 45 \\ Doença do Refluxo Gastroesofágico 46 \\ Doença Hepática Gordurosa Não Alcoólica 48 \\ Doenças Inflamatórias Intestinais $\mathbf{5 0}$ \\ Epilepsia 52
}


Esclerodermia 54

Gastrite crônica 56

Gota 58

Hepatite crônica 60

Hipercolesterolemia 62

Hipertensão 64

Hipertrigliceridemia 66

Intolerância à lactose 67

Insuficiência Renal Crônica 68

Litíase Renal $\mathbf{7 0}$

Lúpus Eritematoso Sistêmico 71

Mal de Parkinson $\mathbf{7 3}$

Megaesôfago 74

Neoplasias 76

Obesidade 78

Obstipação 81

Osteoporose 84

Pancreatite crônica 86

Úlcera péptica 88

\begin{abstract}
3
ANEXOS

Alimentos flatulentos 93

Alimentos funcionais 94

Alimentos laxantes 95

Alimentos obstipantes $\mathbf{9 6}$

Alimentos com alto teor de ácido fólico 97

Alimentos com alto teor de ácido oxálico 98

Alimentos com alto teor de cálcio 99

Alimentos com alto teor de colesterol 100
\end{abstract}


Alimentos com alto teor de enxofre 101

Alimentos com alto teor de ferro 102

Alimentos com alto teor de fibras 103

Alimentos com alto teor de fósforo 104

Alimentos com alto teor de potássio 105

Alimentos com alto teor de sódio 106

Alimentos com alto teor de vitaminas antioxidantes 107

Alimentos com alto teor de gordura trans 109

Tabela Índice glicêmico 111

\section{4 \\ REFERÊNCIAS}



RECOMENDAÇÕES NUTRICIONAIS 

Bons hábitos alimentares permitem atender as necessidades nutricionais, podendo proporcionar bem estar e saúde às pessoas.

\section{RECOMENDAÇÕES}

- Escolher locais tranqüilos para o momento das refeições;

- mastigar bem os alimentos;

- estabelecer e respeitar os horários para as refeições;

- realizar 05 - 06 refeições por dia;

- verificar a quantidade e os nutrientes presentes nos rótulos das embalagens dos produtos alimentar;

- atenção para as datas de validade dos alimentos;

- rejeitar as latas de alimentos que estejam amassadas, enferrujadas ou abauladas;

- aproveitar a água do cozimento de legumes e verduras para a preparação de sopas ou no cozimento de arroz;

- consumir frutas e verduras diariamente;

- acrescentar à alimentação produtos a base de soja e azeite de oliva;

- não usar carnes gordas na preparação dos feijões;

- no preparo das carnes, retirar as gorduras visíveis;

- para as aves retirar a pele antes do cozimento;

- usar sal com moderação;

- utilizar temperos naturais: temperos verdes, alho, cebola, pimentão, tomate, gengibre. 
EVITAR

- beber líquidos em excesso durante as grandes refeições, como almoço e jantar;

- uso abusivo de alimentos enlatados e embutidos, sucos

e sopas industrializadas;

- refrigerantes;

- consumo de bebidas alcoólicas;

- grandes quantidades de café. 
Adolescentes são indivíduos que se encontram no período de transformação entre a infância e a fase adulta, caracterizado por crescimento e desenvolvimento físico, cognitivo, afetivo, moral e social.

\section{RECOMENDAÇõES}

- Incluir na alimentação:

\section{Alimentos energéticos}

Arroz, macarrão, pães, biscoitos, aveia, milho (preferir intregrais) e gorduras saudáveis, como abacate, azeite de oliva extra virgem, nozes, castanhas.

\section{Alimentos protéicos}

Ovos, carnes (aves, bovina, peixe), leite, queijos, iogurtes, feijões, lentilha, grão de bico, soja.

\section{Alimentos ricos em vitaminas e sais minerais}

Vegetais folhosos, frutas, verduras.

- utilizar hortaliças em sucos (laranja com cenoura ou beterraba);

- substituir refrigerantes por sucos naturais, água de coco;

- usar a água do cozimento das verduras para preparar o arroz, feijão, sopas;

- fracionar adequadamente a dieta, fazendo em torno de O5 refeições por dia;

- comer devagar, mastigando bem os alimentos; 
- realizar as refeições em ambientes calmos e tranqüilos;

- não substituir almoço ou jantar por lanches rápidos;

- nos lanches, usar frutas, salada de frutas, barra de cereais de frutas, iogurtes, sanduíches naturais;

- evitar alimentos fritos, como coxinha, pasteis, churros, preferindo os salgados de forno;

- evitar beber líquidos em excesso durante o almoço e jantar;

- não ingerir alimentos com alto teor de açúcares e gordura, como doces, salgadinhos e biscoitos, em horários próximos às principais refeições;

- evitar o uso de frituras e embutidos (presunto, salame, salsicha);

- usar com moderação condimentos, como mostarda, maioneses, requeijão cremoso, catchup;

- beber em torno de 1,5-2,0 litros de líquidos por dia, o que corresponde a 08 - 10 copos de $200 \mathrm{ml}$;

- não exagerar no consumo de bebidas alcoólicas. 


\section{TERCEIRA IDADE}

Terceira Idade é a denominação dada a indivíduos com 60 anos ou mais, que tem necessidades nutricionais particulares relacionadas ao processo de envelhecimento fisiológico.

\section{RECOMENDAÇÕES}

- Alimentar-se em horários regulares, com fracionamento adequado (05 a 06 refeições/dia) e volumes reduzidos;

- ingerir quantidade adequada de líquidos, em média 08 copos/dia de $200 \mathrm{ml}$ água, chás, sucos de frutas, água de coco;

- preferir as carnes brancas (peixe ou frango) ou carnes magras (boi, carneiro) e soja;

- utilizar os alimentos cozidos, assados ou grelhados;

- consumir proteínas de fácil digestão, tais como: carnes brancas, leite desnatado, iogurte, coalhada, queijos tipo Ricota, Minas, Cottage, clara de ovo;

- fazer uso de alimentos ricos em cálcio: leite, queijo, iogurte, coalhada, gema de ovo (1-2 vezes/semana), peixes (sardinha, badejo, salmão, merluza), feijão branco, soja, semente gergelim, amêndoa, aveia, vegetais verdes escuros (brócolis, repolho, folhas de beterraba, mostarda, espinafre, couve, quiabo);

- utilizar alimentos ricos em ferro: fígado, carnes magra, 
feijões secos, grão de bico, lentilha, amendoim, folhas verdes escuras (espinafre, brócolis, couve), frutos secos (banana passa, uva passa), melaço;

- consumir alimentos ricos em vitamina C: frutas cítricas como laranja, limão, tangerina, lima, caju, goiaba, abacaxi, melão, acerola;

- fazer uso de óleo de origem vegetal, como girassol, canola, soja, milho.

\section{EVITAR}

- ingerir líquidos em excesso durante as refeições;

- alimentos muito condimentados;

- produtos defumados e industrializados;

- preparações muito quentes ou muito frias;

- excesso café, refrigerante, chocolate;

- alimentos que não fornecem vitaminas e minerais, mas apenas calorias, como: doces, tortas, balas, açúcar branco. 
Atleta é o indivíduo que pratica exercício físico intenso, objetivando obter maior disposição e resistência e confiança em si mesmo, com a finalidade de conseguir êxito em competições esportivas.

\section{RECOMENDAÇõES}

- Consumir alimentos ricos em carboidratos, como os pães, cereais e massas;

- as proteínas de origem vegetal devem ser acompanhadas por proteínas de origem animal;

- não omitir uma refeição, pois estará perdendo preciosas reservas de glicogênio e nutrientes;

- usar suplemento nutricional sob orientação do nutricionista.

\section{PRÉ-COMPETIÇÃ̃}

- nos dias anteriores a competição, aumentar a quota de carboidratos da dieta, dando preferência aos complexos (como os cereais integrais);

- evitar alimentos ricos em gordura;

- evitar chás, café e álcool.

\section{DIA DA COMPETIÇÃO}

- não exagerar na quantidade de alimentos; 
- evitar os alimentos desconhecidos ou muito condimentados;

- a refeição sólida deve anteceder 4 horas antes da competição;

- evitar frituras ou preparações com grande quantidade de gordura;

- mastigar bem os alimentos;

- fazer as refeições em ambiente calmo;

- não consumir alimentos que promovam a formação de gases abdominais (repolho, batata-doce, pepino, pães).

\section{PÓS COMPETIÇÃO}

- ingerir grandes quantidades de líquidos;

- preferir alimentos como legumes, frutas e pães. 
TERAPÊUTICA NUTRICIONAL 

A Anemia Falciforme é uma doença hereditária, em que os glóbulos vermelhos têm a forma alterada, tornando-se parecidos com uma foice. Estes se agregam nos vasos sanguíneos, dificultando a circulação nos microvasos.

\section{RECOMENDAÇÕES}

- Ingerir bastante líquidos, no mínimo 10 copos de 200 $\mathrm{ml}$ de líquidos/dia; caso realize atividade física ou apresente febre ou calor excessivo é necessário aumentar essa quantidade (3 a 5 litros por dia);

- consumir alimentos com alto teor de ácido fólico, como folhosos (de preferência crus), iogurte, peixe, passas, abacaxi, aveia;

- excluir alimentos com alto teor de ferro, como fígado, miúdos, fórmulas enriquecidas com ferro;

- ingerir alimentos com alto teor de vitamina C, como laranja, goiaba, caju, acerola, açaí, mas evitando-os durante as principais refeições (almoço e jantar);

- estimular a ingestão de chá mate ou chá preto, café após as principais refeições;

- utilizar verduras, frutas, leguminosas, leites e carnes;

- preferir carnes brancas: peixes e frango;

- não tome medicamentos que contenham ferro sem conversar com profissional de saúde. 
A Anemia Ferropriva ocorre quando há uma concentração reduzida de hemoglobina no sangue e diminuição no conteúdo de ferro total do organismo.

\section{CONSUMIR}

- vísceras: fígado, rim, coração, moela, língua de vaca;

- carnes: bovina, aves e peixe;

- leguminosas secas: ervilha, lentilha, grão de bico;

- legumes: quiabo, jiló, beterraba;

- inhame, aveia;

- frutas: jenipapo, araçá. Nas sobremesas faça uso de frutas secas a exemplo de figo, ameixa, uva-passa, banana-passa;

- rapadura, melaço de cana, açúcar mascavo;

- gema de ovo, marisco de conchas (ostra, sururu);

- ingerir junto aos alimentos fontes de ferro alimentos com alto teor em vitamina C, como limão, laranja, caju, acerola, abacaxi, melão, sapoti, lima, tangerina, umbu;

- evitar: chá, refrigerante, café e álcool, pois diminuem a absorção intestinal do ferro;

- não consumir leite e derivados junto às refeições com alto teor de ferro. 


\section{ANOREXIA NERVOSA}

A Anorexia Nervosa é uma doença caracterizada pela grande perda ponderal autoprovocada, amenorréia e psicopatologia específica.

\section{FASE AGUDA DA DESNUTRIÇÃO}

- utilizar alimentos liquefeitos e enriquecidos (sucos, sopas, mingaus);

- evoluir para preparações pastosas (sopas enriquecidas, mingaus, vitaminas, purê).

\section{EVOLUÇÃO DO QUADRO}

- evitar o consumo de alimentos gordurosos;

- não utilizar frituras;

- fazer ingestão de cereais, leguminosas, doces, bolos, sorvetes;

- ingerir as frutas, sem engolir as cascas e o bagaço;

- cozinhar as verduras;

- aumentar gradativamente a ingestão de ovos, carnes, peixes, aves;

- aumentar ingestão de líquidos;

- aumentar o fracionamento das refeições;

- reduzir o volume. 


\section{ATENTAR PARA}

- aparência e colorido das refeições;

- o local da alimentação, que deve ser agradável e arejado;

- cardápio variado;

- utilização aumentada de condimentos;

- empatia com a pessoa que lhe serve a refeição. 
Cardiopatias são patologias congênitas ou adquiridas que afetam o músculo cardíaco.

\section{RECOMENDAÇÔES}

- utilizar dieta hipossódica, ou seja, sem adição ou com diminuição do sal de cozinha;

- usar nas preparações: limão, azeite de oliva, alho, cebola, pimentão, salsa, coentro, hortelã, manjericão, cebolinha, noz moscada, gengibre, tomate, orégano;

- observar os rótulos dos alimentos industrializados, identificando o valor de sódio no produto;

- não usar alimentos dietéticos indiscriminadamente;

- substituir o pão de sal, por bolacha d’água, aipim, inhame, batata doce, banana da terra;

- preferir creme vegetal, como substituto de manteiga ou margarina;

- usar óleos de origem vegetal com moderação: girassol, arroz, soja, canola, milho;

- não ingerir preparações gordurosas como feijoada, mocotó, dobradinha, sarapatel, caruru, moquecas, cozidos;

- retirar a pele do frango antes do preparo;

- preferir alimentos assados, grelhados ou cozidos; 
- consumir ovos cozidos ou preparados em água;

- consumir frequentemente frutas, verduras e leguminosas;

- dar preferência aos lanches e sobremesas compostas de frutas;

- preferir alimentos integrais: pães, biscoitos, arroz, farelos;

- ingerir de 08 a 10 copos de $200 \mathrm{ml}$ de líquidos ao dia (sucos, água, chás, água de coco), caso não haja restrição de líquidos na dieta;

- mastigar bem os alimentos;

- alimentar-se em ambiente calmo, utilizando roupas folgadas;

- fazer de 05 a 06 refeições ao dia, mantendo regularidade nos horários.

\section{EVITAR}

- frituras;

- excesso de bebidas excitantes: chá preto ou mate, refrigerantes, chocolate, café;

- alimentos que já contenham sal como: enlatados, embutidos, queijos com sal, molhos industrializados, sopas em pacotes, caldos em tablete, salgadinhos, carnes secas e salgadas;

- doces em excesso;

- alimentos formadores de gases como repolho, batatadoce, pepino, pães;

- situações estressantes;

- bebidas alcoólicas. 


\section{CEFALÉIAS}

O termo "cefaléia" se aplica a um grupo de síndromes clínicas, cujo estágio final da patogênese da dor parece ser a dilatação de um ou mais ramos da artéria carótida, levando à estimulação das terminações nervosas que suprem essa artéria.

\section{RECOMENDAÇÔES}

- ingerir de 8 a 10 copos (200 ml) de água por dia, filtrada ou fervida;

- não permanecer por longo tempo em jejum;

\section{EVITAR OS ALIMENTOS QUE CONTENHAM}

- álcool;

- aspartame, como os adoçantes;

- cafeína (café, chá, refrigerantes tipo cola);

- tiramina;

- glutamato monossódico.

\section{ALIMENTOS COM ALTO TEOR DE GLUTAMATO MONOSSÓDICO}

alimentos dietéticos

caldos em tabletes

aromatizantes naturais

enlatados

batata frita 
maioneses

comida congelada

proteína animal hidrolizada

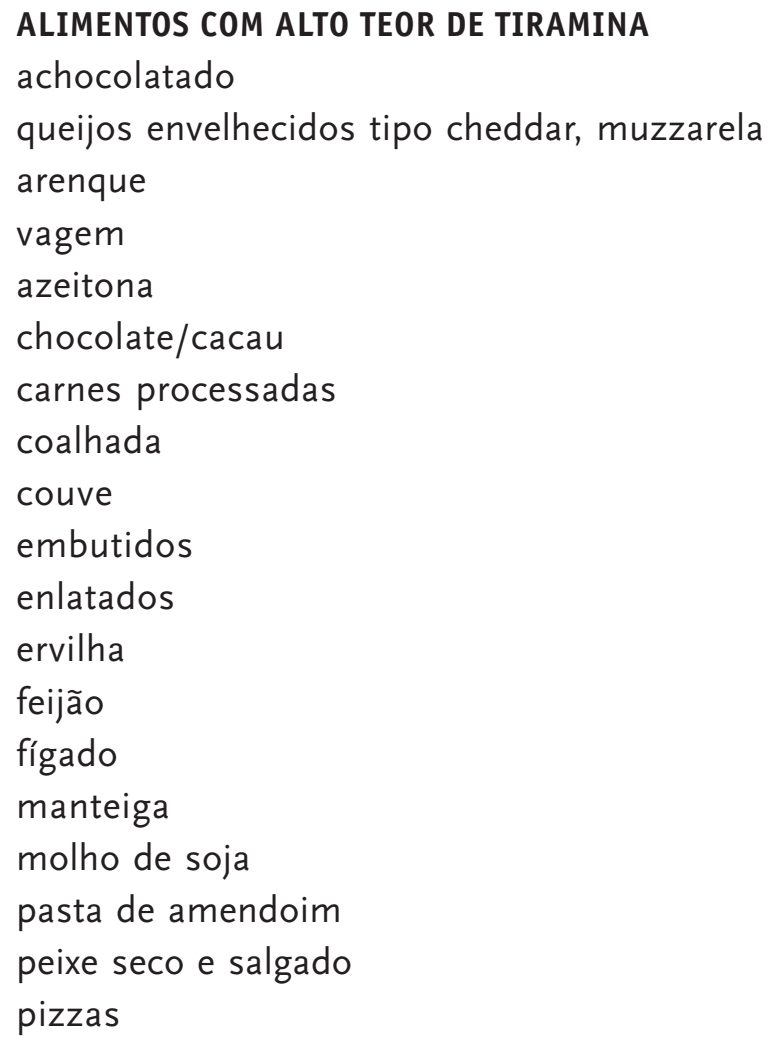




\section{CIRURGIA BARIÁTRICA}

Tratamento cirúrgico de pacientes com obesidade grave, que preenchem critérios específicos. O objetivo da cirurgia é reduzir a capacidade gástrica e/ou redução da absorção de nutrientes.

PRÉ-CIRURGIA - dieta hipocalórica para emagrecimento de 5

a 10\%, visando redução das complicações pós-cirurgicas:

- realizar de 05 a 06 pequenas refeições por dia, em horários estabelecidos;

- comer devagar, mastigando bem os alimentos;

- usar adoçantes não calóricos;

- preferir preparações assadas, cozidas ou grelhadas;

- consumir diariamente frutas e verduras;

\section{EVITAR}

- "beliscar";

- pular refeições;

- açúcar, doces, tortas;

- frituras;

- preparações gordurosas, com excesso de óleo/margarina, creme de leite, maionese, azeite de dendê, carnes gordas. 


\section{PÓS-CIRURGIA}

- usar dieta líquida no primeiro mês: água de coco, chás claros, sucos coados de frutas não ácidas, caldos coados de legumes, carne magra, frango e peixe (sem pele), leite e iogurtes desnatados;

- preferir líquidos na temperatura quente;

- nas primeiras duas semanas, consumir pequenos volumes (50 $\mathrm{ml}$ de 2/2 horas);

- ingerir os líquidos com auxílio de uma colher;

- manter ingestão de no mínimo 2 litros de água por dia, observando intervalo de 40 minutos antes e após as refeições;

- após 4 semanas, evoluir consistência da dieta para pastosa, acrescentando um alimento por vez a depender da tolerância;

- realizar as refeições em ambientes tranqüilos;

- mastigar bem os alimentos (vagarosamente), com duração de no mínimo 40 minutos;

- não omitir nenhuma refeição;

- não "beliscar";

- ingerir apenas os alimentos que não lhe causem desconforto;

- não deitar logo após as refeições;

- ingerir 2 litros de água por dia, fora das refeições;

- consumir diariamente frutas e verduras;

- utilizar diariamente clara de ovo, em preparações como saladas;

- usar suplementos vitamínico-minerais sob orientação médico-nutricional; 


\section{NÃO CONSUMIR}

- bebidas alcoólicas;

- bebidas gasosas;

- alimentos fibrosos, como bagaço das frutas e vegetais crus;

- doces, açúcar, mel, pudim, leite condensado, sorvete;

- frituras e preparações gordurosas.

$\mathrm{Na}$ fase de adaptação final e independência alimentar:

- introduzir frutas com bagaço e vegetais crus;

- ingerir alimentos com alto teor de ferro, cálcio, proteínas, vitamina $\mathrm{C}$, vitamina $\mathrm{A}$ e folatos. 


\section{COLOSTOMIA}

A Colostomia é uma abertura da parede cólica, comumente utilizada quando se necessita fazer a ressecção de parte do intestino, buscando uma alternativa para a eliminação das fezes.

\section{RECOMENDAÇõES}

- Aumentar o fracionamento da dieta, em torno de o6 refeições por dia;

- reduzir o volume das refeições;

- mastigar bastante os alimentos;

- alimentar-se em ambiente tranqüilo;

- ingerir líquidos em quantidade adequada: 8-10 copos de $200 \mathrm{ml}$ de líquidos por dia;

- consumir vegetais cozidos e não folhosos;

- a dieta deve conter todos os nutrientes, por isso deve-se consumir frutas, verduras, cereais, carnes.

\section{EVITAR}

- alimentos flatulentos como repolho, batata-doce, feijão, refrigerantes;

- alimentos ricos em enxofre: milho, agrião, aipo, brócolis, cebola, couve, couve-flor, bertalha, nabo, pimentão, repolho, rabanete, taioba, caruru, grão de bico, feijãopreto, manteiga, carnes vermelhas, peixes, queijos amarelos, mariscos; 
- concentrados de açúcar, como sobremesas açucaradas, chocolate, doces em calda;

- frituras em geral;

- alimentos em conserva, como milho, ervilha, azeitona enlatados;

- alimentos gordurosos: sarapatel, mocotó, caruru, moquecas, feijoada.

Antibióticos e alguns suplementos vitamínico-minerais podem causar odor desagradável. 


\section{DIABETES MELLITUS}

Diabetes Mellitus é uma alteração metabólica, crônica, degenerativa, caracterizada pela insuficiência relativa ou absoluta de insulina.

\section{RECOMENDAÇÕES}

- realizar 05 a 06 pequenas refeições por dia, em horários estabelecidos;

- usar adoçante com moderação ou preferir os alimentos ao natural;

- consumir vegetais, preferindo folhosos (acelga, agrião, alface, brócolis, repolho, couve, espinafre);

- preferir alimentos integrais, como pães, biscoitos, arroz;

- utilizar farinhas de tapioca, milho ou aveia;

- preferir carnes brancas (aves e peixes), retirando a pele antes das preparações;

- fazer uma refeição leve antes de dormir: leite, iogurte, sucos, frutas;

- ingerir 10 copos (200ml) de água por dia.

\section{EVITAR}

- alimentos contendo açúcar: balas, bolo, doces, chocolates, refrigerantes, mel, rapadura, sorvetes, achocolatados em pó;

- farináceos: farinha de mandioca, arroz, amido de milho e outras que contenham açúcar na composição; 
- jejum prolongado ou excesso de alimentação;

- frituras;

- alimentos ricos em gordura animal, como carnes, leite integral, creme de leite, requeijão, bacon, manteiga, toucinho, banha, queijos amarelos, chouriça, charque;

- bebidas alcoólicas;

\section{RECOMENDAÇÕES GERAIS}

- seguir a orientação nutricional prescrita;

- fazer uso das medicações prescritas;

- praticar exercícios físicos orientados;

- realizar os testes de sangue e/ou urina regularmente;

- evitar o fumo.

HIPOGLICEMIA: baixa do nível de glicose no sangue

\section{Causas}

- não ingestão da quantidade de alimentos prescritas na orientação nutricional, ou atraso ou omissão de alguma refeição;

- realizar exercício físico em excesso associado a uma alimentação inadequada;

- baixa ingestão de calorias associada a uma dosagem excessiva de insulina ou hipoglicemiantes orais;

- perdas alimentares pôr vômitos ou diarréia.

\section{Sintomas}

sudorese

dor de cabeça

palidez 
fraqueza

palpitações

tontura

Traga sempre consigo um pequeno doce ou balas e coloque na boca ao sentir os primeiros sinais da hipoglicemia. 


\section{DIARRÉIA}

A Diarréia se caracteriza por um aumento do número (mais de 3 dejeções) e modificação na consistência das evacuações nas 24 horas, podendo conter sangue, pus ou muco.

\section{RECOMENDAÇõES}

- não suspender a alimentação;

- aumentar a hidratação (10-12 copos/dia) com água filtrada ou fervida, água de coco, chás (entrecasca do coco, folha de goiaba), água de arroz, sucos (maçã, lima coado, goiaba, caju);

- fazer uso de alimentos obstipantes: maçã sem casca, banana da prata, caju, goiaba, lima, laranja-lima, pêra, suco de limão, arroz branco, mucilagem de arroz, amido de milho (maizena);

- dar preferência a vegetais cozidos como: cenoura, batata, chuchu, beterraba, vagem, batata-doce, inhame, fruta-pão;

- dar preferência às carnes brancas peixe, aves grelhadas, assadas ou cozidas;

- preferir o pão torrado, biscoitos de água e sal;

- ingerir leite desnatado, fermentado e iogurte natural;

- utilizar os queijos com baixo teor de gordura;

- lavar em água corrente frutas e verduras que for consumir crus e deixar durante 15 minutos em água sanitária diluída (1 colher de sopa para cada 1 litro de água); 
- usar sais de reidratação oral (diluir 1 pacote em 1 litro de água filtrada ou fervida).

\section{EVITAR}

- frutas secas e oleagenosos, como nozes, avelã, castanhas, amendoim, abacate;

- vegetais folhosos, como alface, agrião, espinafre, acelga, couve, brócolis;

- frutas como: laranja, ameixa, mamão, abacaxi, uva, morango, tamarindo, abacate;

- chocolates, frituras, condimentos como catchup, mostarda, orégano, pimenta do reino, molho inglês;

- alimentos ricos em enxofre, como: agrião, aipo, brócolis, cebola, couve, couve-flor, bertalha, espinafre, nabo, pimentão, repolho, rabanete, taioba, caruru, grão de bico, feijão-preto, manteiga, carnes vermelhas;

- bebidas gaseificadas como refrigerantes, água com gás;

- bebidas alcoólicas. 
Dislipidemias são alterações metabólicas lipídicas nos níveis séricos de colesterol total e frações e/ou triglicerídes.

\section{RECOMENDAÇÕES}

- preferir carnes brancas (aves e peixes);

- consumir preferencialmente, os peixes de água profundas e frias como arenque, salmão, sardinha, cavala;

- consumir freqüentemente soja;

- usar óleos vegetais como soja, canola, milho, arroz (exceto de coco e palma);

- utilizar azeite de oliva extra virgem, cru, podendo ser acrescido em pães, saladas;

- preferir creme vegetal como substituto da manteiga e margarina;

- usar leite desnatado e derivados (iogurte desnatado, queijo);

- utilizar alimentos integrais (pães, biscoitos, arroz);

- fazer uso de farelos de trigo, farelo de aveia e linhaça;

- utilizar alho (natural) para preparo dos alimentos;

- consumir diariamente frutas e verduras;

\section{EVITAR}

- carnes vermelhas, de porco, vísceras (fígado, miolo, miúdos), pele de aves (frango, peru), frutos do mar como camarão, caranguejo, ostras; 
- gordura de origem animal das carnes, leite integral, creme de leite, requeijão, bacon, manteiga, toucinho, banha;

- preparações fritas;

- alimentos embutidos como chouriça, paio, salsicha, e salgadinhos;

- azeite de dendê, leite de coco, chocolates;

- excesso de café, se possível coado;

- excesso de massas (macarronada, lasanha, pizzas);

- excesso de açúcar e de preparações que a contenham, mel, rapadura, pães, biscoitos;

- refrigerantes;

- bebidas alcoólicas. 


\section{DOENÇA CELÍACA}

A Doença Celíaca é uma doença caracterizada pela má absorção, tendo como causa a intolerância ao glúten.

\section{ALIMENTOS PROIBIDOS}

- alimentos que contenham trigo, aveia, centeio e cevada na sua composição;

- farinhas e farelos;

- pão, miolo de pão, bolachas, panquecas e roscas;

- carnes enlatadas, carne à milanesa, patês enlatados, frios com farináceos (salame, salaminho, salsichas);

- molhos comerciais de saladas (maionese, catchup, mostarda);

- bolos, massas, sopas industrializadas, pudim engrossado com trigo, caldos em tabletes;

- sorvetes comerciais;

- leite maltado, cafés misturados com cevada, achocolatados;

- cerveja, uísque, vodka, gin;

- ler os rótulos das embalagens verificando a presença do trigo, aveia, centeio e cevada ou a expressão conTÉm GLÚTEN.

\section{ALIMENTOS PERMITIDOS}

- leite e derivados (queijo, iogurte, creme de leite, leite condensado e manteiga), ovos; 
- sopas puras, de vegetais, engrossados com creme de maizena ou batata;

- pão de arroz, milho, batata, soja (isento de glúten);

- farinhas de milho, arroz, tapioca, sagú e puba;

- milho: cuscuz, canjica, pipoca;

- inhame, aimpim, banana-da-terra, batata doce, fruta pão;

- vegetais sem restrição;

- frutas à vontade;

- sobremesas: gelatinas, refrescos de frutas, pudins de arroz e maizena, geléias, doces e sorvetes caseiros;

- bebidas: suco de frutas, bebidas gasosas, chá, café (sem glúten), vinho, champanhe. 


\section{DOENÇA DIVERTICULAR}

A Doença Diverticular é a uma enfermidade do intestino grosso que se caracteriza pela presença de divertículos.

\section{RECOMENDAÇÕES}

- a dieta deve ser rica em fibras, encontradas principalmente nas hortaliças, grãos, cereais integrais, cascas de frutas, nos talos e folhas de vegetais:

\begin{tabular}{|l|l|l} 
ameixa & farelo de trigo & milho \\
abacaxi & folhosos (couve, alface) & pão intregal \\
abóbora & gerne de trigo & pepino \\
arroz integral & laranja & quiabo \\
cenoura crua & mamão & tomate
\end{tabular}

- aumentar a ingestão de líquidos, no mínimo 2 litros de água por dia.

\section{EVITAR}

- a ingestão das sementes de frutas;

- alimentos que causem cólicas ou desconforto. 
A Doença do Refluxo Gastroesofágico caracteriza-se pela ocorrência de complicações do movimento do conteúdo gástrico para o esôfago ou orofaringe.

\section{RECOMENDAÇÕES}

- fracionar a alimentação em 05 a 06 pequenas refeições por dia;

- alimentar-se devagar, mastigando bem os alimentos e em ambiente tranqüilo;

- consumir preferencialmente, vegetais cozidos;

- preferir as preparações assadas, grelhadas ou cozidas;

- retirar toda a gordura visível das carnes e pele de aves antes da cocção;

- usar leite e iogurte desnatados e queijos com baixo teor de gordura;

\section{EVITAR}

- bebidas alcoólicas;

- líquidos durante as refeições;

- alimentos ricos em cafeína, como café, chocolate, bebidas tipo cola;

- alimentos carminativos, como hortelã, canela, menta;

- preparações gordurosas, como mocotó, sarapatel, dobradinha, feijoada, caruru, frituras;

- alimentos muito condimentados; 
- alimentos que causem desconforto.

\section{RECOMENDAÇÕES GERAIS}

- fazer as refeições em posição ereta;

- não deitar após as refeições;

- elevar a cabeceira da cama de 20 a $25 \mathrm{~cm}$;

- evitar roupas e cintos apertados;

- manter o peso adequado;

- evitar o fumo. 


\section{DOENÇA HEPÁTICA GORDUROSA NÃO ALCOÓLICA}

A Doença Hepática Gordurosa Não Alcoólica caracteriza-se pelo acumulo de gordura nas células hepáticas, podendo evoluir para hepatite, cirrose, carcinoma hepatocelular e ocorre em pacientes sem história de consumo significativo de álcool (<2og de etanol / dia).

\section{RECOMENDAÇÕES}

- fracionar a alimentação em 05 a 06 refeições por dia;

- mastigar lentamente os alimentos;

\section{UTILIZAR}

- azeite de oliva extra-virgem (não levar ao fogo);

- óleos de origem vegetal arroz, milho, canola, soja;

- farelo de aveia, farelo de trigo, linhaça;

- carnes brancas, retirando a pele antes da cocção;

- leite desnatado;

- queijo frescal, ricota e cottage;

- frutas e verduras diariamente;

- saladas cruas;

- alimentos integrais: pães, biscoitos, arroz;

- adoçante artificial;

- soja; 


\section{EVITAR}

- alimentos ricos em gorduras, como carnes vermelhas e preparações gordurosas, como sarapatel, feijoada, mocotó;

- frituras;

- produtos achocolatados, líquidos ou em pó;

- embutidos (salame, chouriça, presunto, salsicha, lingüiça, calabresa);

- consumo excessivo de massas, doces, mel, refrigerantes.

\section{PROIBIDO}

- bebidas alcoólicas. 


\section{DOENÇAS INFLAMATÓRIAS INTESTINAIS}

As Doenças Inflamatórias Intestinais incluem a Doença de Crohn e a Retocolite ulcerativa. A Doença de Crohn compreende uma enfermidade crônica, que pode ocorrer em qualquer segmento do tubo digestivo, sendo o íleo a principal sede desta doença. A Retocolite ulcerativa é uma inflamação crônica, com ulceração da mucosa do intestino grosso, atingindo principalmente o cólon descendente, sigmóide e reto.

\section{FASE ATIVA}

- aumentar o fracionamento da dieta (6 refeições por dia);

- consumir frutas diariamente;

- preferir vegetais cozidos;

- usar alimentos obstipantes, como maçã sem casca, goiaba, caju, maisena, farinha de arroz;

- utilizar adoçante;

- ingerir 10-12 copos/dia com água filtrada ou fervida;

- não fazer uso do leite de vaca;

- usar leite de soja ou isento de lactose;

- consumir queijos (ricota, minas, cottage) e produtos fermentados como iogurte desnatado, de acordo com a tolerância;

- não utilizar alimentos gordurosos;

- preferir preparações cozidas, assadas ou grelhadas; 


\section{EVITAR}

- refeições volumosas;

- doces, tortas, pães, massas e açúcar;

- alimentos com alto teor de sódio: salgadinhos, temperos industrializados, enlatados, embutidos;

- alimentos laxantes, como laranja, ameixa, mamão, miIho, folhosos (agrião, couve, repolho, espinafre);

- alimentos que causem desconforto;

- frituras.

\section{FASE REMISSÃO}

- usar leite de vaca e derivados;

- consumir peixes com freqüência;

- ingerir frutas e verduras diariamente;

- utilizar alimentos com alto teor de ácido fólico, como folhosos, fígado, banana, iogurte, pão integral;

- consumir alimentos com alto teor de vitamina $B_{12}$ : carnes, leite, ovos;

- ingerir alimentos com alto teor de vitamina C (acerola, caju, goiaba, limão);

- lavar em água corrente, frutas e verduras que for consumir crus e deixar durante 15 minutos em água sanitária diluída (1 colher de sopa para cada 1 litro de água). 
Epilepsia é uma alteração temporária e reversível do funcionamento do cérebro, que não tenha sido causada por febre, drogas ou distúrbios metabólicos.

\section{RECOMENDAÇõES}

- respeitar os horários das refeições, evitando jejum prolongado;

- evitar ingerir bebidas alcoólicas;

- ingerir alimentos com alto teor de cálcio (queijo, leite, mariscos, tofu, grão de bico);

- evitar alimentos com alto teor de ácido fólico (folhosos verdes, como agrião, alface, couve, espinafre; fígado, carne bovina magra, ovos, peixe, feijões seco, trigo, lentilha, levedo de cerveja, pão integral).

\section{DIETA CETOGÊNICA}

A dieta cetogênica é empregada, principalmente nas crianças, que não obtém melhoras das crises com o uso de anticonvulsivantes. Esta dieta é rica em gordura e pobre em carboidratos, visando alcançar cetose. É necessário cálculo preciso de macronutrientes.

- iniciar após jejum de 48 a 72 horas (hospitalizado);

- ingerir bastante alimentos gordurosos (presunto, salsicha, ovos, peixes, azeite de oliva, carnes, queijo, creme de leite, maionese) - 90\% do VET; 
- evitar ingestão de doces, tortas, bolos, sobremesas, sorvetes, massas, pães, biscoitos, mel;

- introduzir os alimentos ricos em carboidratos na dieta segundo orientações do nutricionista, após 03 meses sem apresentar ataques epilépticos.

A dieta é desagradável e difícil de seguir. Efeitos colaterais: náusea, vômitos, diarréia, perda de peso, irritabilidade. Duração: menos de $2-3$ meses. É mais efetiva em crianças. 
A Esclerodermia é uma doença multissistêmica, caracterizada por lesões vasculares proliferativas em arteríolas e micro-circulação, distúrbio generalizado do tecido conjuntivo, evoluindo com espessamento e fibrose da pele, sinóvia, artérias digitais e vários órgãos.

\section{RECOMENDAÇÕES}

- fracionar a dieta em o6 refeições ao dia;

- mastigar lentamente os alimentos;

- adequar a consistência à tolerância do pacientes;

- consumir uma dieta rica em frutas e verduras, legumes e cereais;

- preferir preparações assadas, grelhadas ou cozidas;

- preferir carnes brancas (aves e peixes), retirando a pele das aves antes das preparações;

- utilizar óleos vegetais (milho, soja, oliva, algodão, girassol);

- ingerir de 08-10 copos (200 ml) de líquidos/dia;

- consumir alimentos com alto teor de cálcio: leites e derivados, folhosos verde-escuro, peixes;

- utilizar queijos com pouca gordura (Minas Frescal, Ricota, Cottage);

- substituir pães e bolachas salgadas por: pão sem sal, bolacha d'água, aipim, inhame, batata doce, banana da terra; 
- Usar limão, azeite doce, temperos verdes, alho, cebola, pimentão, noz moscada, orégano, manjericão, alecrim, para melhorar o sabor dos alimentos;

- Usar adoçante.

\section{EVITAR}

- refeições volumosas;

- embutidos: calabresa, salame, mortadela, salsicha;

- peixes enlatados, presunto, bacon, azeitonas, picles, temperos prontos, sopas desidratadas, concentrados em cubos, charque, catchup, maionese, manteiga c/ sal;

- doces, tortas, pudins, sobremesas e açúcar;

- consumo de bebidas alcoólicas. 
A gastrite crônica é uma inflamação da mucosa gástrica, com atrofia cônica progressiva dessa mucosa.

\section{RECOMENDAÇÕES}

- realizar refeições em pequeno volume e freqüentes (05-06 refeições por dia);

- fazer as refeições com calma e em lugares sossegados;

- mastigar bem os alimentos;

- observar e evitar alimentos que causem desconforto;

- consumir frutas ácidas de acordo com a tolerância;

- preferir a utilização de vegetais cozidos;

- dar preferência às carnes brancas (peixe e aves), retirando a pele das aves antes da cocção;

- consumir alimentos com alto teor de vitamina $B_{12}$ : carne de boi magra, aves, peixe, leite desnatado, ovos cozidos;

\section{EVITAR}

- frituras e alimentos gordurosos;

- ingerir líquidos em excesso durante as refeições principais (almoço e jantar);

- bebidas que contenham cafeína, como refrigerantes, chocolates, café, chá mate, chá preto;

- bebidas alcoólicas; 
- condimentos (pimenta do reino, mostarda, orégano, catchup);

- alimentos excessivamente gelados ou quentes;

- substituir as refeições por lanches rápidos;

- períodos de jejum ou de excesso de alimentação;

- alimentos ricos em enxofre: cebola, repolho, brócolis, feijão, quiabo, couve-flor, espinafre, agrião, ovo cozido, pimentão;

\section{RECOMENDAÇÕES GERAIS}

\section{EVITAR}

- situações estressantes;

- fumo;

- álcool;

- uso de antiinflamatórios;

- medicamentos sem a devida orientação médica. 
A Gota é o uma doença crônica, proveniente da alteração do metabolismo das purinas, caracterizada pelo aumento do ácido úrico no sangue.

\section{RECOMENDAÇõES}

- fazer uso de dieta pobre em purinas;

- evitar ingestão de gorduras: frituras ou preparações gordurosas como feijoada, sarapatel, caruru;

- evitar ingestão de bebidas alcoólicas;

- evitar longos períodos de jejum;

- aumentar a ingestão de líquidos para mais de 03 litros por dia;

- a quantidade de sódio da dieta deve ser normal ou reduzida, segundo orientação do nutricionista;

\section{FASE AGUDA}

- excluir alimentos com alto teor em purinas;

- ingerir bastante líquidos.

\section{FASE INTERMEDIÁRIA}

- consumir moderadamente alimentos com médio teor em purinas;

- evitar ingerir quantidades excessivas de alimentos como carnes e leguminosas. 


\section{Alimentos que devem ser eliminados da dieta pelo teor de purinas}

Caldo de carne em tabletes

Mexilhão

Embutidos

Ovas de peixe

Fígado, coração, língua, rim e miolos

Peixes (sardinha, salmão, bacalhau)

logurte

Tomate e extrato de tomate

Lêvedos

Vitela, bacon

Molhos industrializados

\section{Usar com Moderação}

Carnes e aves

Cereais integrais como arroz integral, trigo em grão, centeio e aveia

Espinafre, aspargos, couve-flor, cogumelo

Feijão, soja, vagem, lentilha, ervilha

Oleaginosas como coco, nozes, amendoim, castanhas, pistache, avelã

Peixe e mariscos (camarão, ostra, lagosta, caranguejo)

\section{RECOMENDAÇÃO GERAL}

- manter o peso dentro dos limites de normalidade;

- praticar exercício físico diariamente, sob orientação de um profissional. 


\section{HEPATITE CRÔNICA}

Hepatite é um processo inflamatório do fígado, que pode evoluir com degeneração e necrose de hepatócitos, sendo causada por vírus, drogas, parasitas ou substâncias tóxicas.

\section{RECOMENDAÇÕES}

- fracionar a alimentação diária de 05 a 06 vezes;

- diminuir o volume das refeições;

- consumir uma dieta composta de massas, frutas, verduras, cereais, leguminosas;

- utilizar leite desnatado, queijo branco como minas, ricota, cottage;

- preferir carnes brancas (aves, peixe), soja;

- retirar a pele de frango antes de prepará-lo;

- utilizar óleo de origem vegetal como milho, soja, canola;

- não ingerir bebidas alcoólicas;

\section{EVITAR}

- maionese, excesso manteiga/margarina, carnes gordas;

- preparações gordurosas como sarapatel, feijoada, mocotó, cozido;

- frituras;

- produtos achocolatados;

- excesso de sal;

- embutidos (salame, salsicha, lingüiça, calabresa);

- enlatados (ervilha, azeitona, milho, sardinha). 


\section{RECOMENDAÇÃO GERAL}

- manter o peso dentro dos limites de normalidade. 
Hipercolesterolemia ocorre quando o nível plasmático de colesterol está elevado.

\section{RECOMENDAÇÕES}

- fracionar adequadamente as refeições (05-06 refeições/dia);

- ingerir diariamente frutas, verduras, vegetais folhosos;

- utilizar farelo de aveia, farelo de trigo, linhaça;

- consumir soja frequentemente;

- preferir carnes brancas (aves e peixes);

- consumir preferencialmente, os peixes de água profundas e frias como arenque, salmão, sardinha, cavala;

- preferir as preparações cozidas, assadas ou grelhadas;

- usar de preferência óleos vegetais como soja, milho, girassol, canola;

- preferir creme vegetal como substituto da manteiga e margarina;

- usar leite desnatado e derivados (iogurte desnatado, queijo com baixo teor de gordura);

- utilizar azeite de oliva extra-virgem em pães e preparo de saladas;

- preferir alimentos integrais (pães, biscoitos, arroz);

- fazer uso de farelo de trigo, farelo de aveia e linhaça;

- utilizar alho (natural) para preparo dos alimentos;

- consumir ovos cozidos ou preparados em água; 


\section{EVITAR}

- pães recheados, massas prontas, bolachas picantes, brioches, biscoitos amanteigados, croissant;

- recheios e coberturas de chocolate, tortas, bolos, barras de chocolate e de coco;

- achocolatados;

- salgadinhos fritos (batata frita, salgadinhos industrializados, pastel, cochinha, churros), sorvetes a base de leite, milk shake;

- molhos à base de manteigas e cremes;

- cremes para café;

- frituras;

- gordura visível na carne, bacon, banha, toucinho, pele de aves, rim, fígado, coração, porco;

- embutidos como salame, presunto, mortadela, salsichas, lingüiça;

- creme de leite, leite condensado, nata de leite, manteiga, queijos cremosos, requeijão, leite integral e iogurte integral;

- azeite de dendê, leite de coco;

- frutos do mar: camarão, lagosta, caranguejo, ostras;

- bebidas alcoólicas. 
A Hipertensão é uma patologia que se caracteriza pela elevação dos níveis pressóricos.

\section{RECOMENDAÇõES}

- utilizar dieta rica em frutas e verduras principalmente cruas, legumes e cereais;

- reduzir o sal das preparações, seguindo as orientações do nutricionista;

- substituir pães e bolachas salgadas por pão sem sal, bolacha d'água, aipim, inhame, batata doce, banana da terra;

- preferir creme vegetal sem sal em substituto da manteiga ou margarina sem sal;

- usar limão, azeite de oliva extra-virgem, coentro, cebolinha, salsa, hortelã, folha de louro, alho, cebola, pimentão, noz moscada, orégano, manjericão, alecrim, urucum, para melhorar o sabor dos alimentos;

- preferir preparações assadas, grelhadas ou cozidas;

- utilizar óleos vegetais como milho, soja, oliva, algodão, girassol;

- usar leite desnatado;

- consumir queijos com pouca gordura (minas, ricota, cottage);

- ingerir de 08-10 copos (200 ml) de líquidos/dia; 


\section{EVITAR}

- embutidos como calabresa, salame, presunto, mortadela, salsicha;

- enlatados: peixes, azeitonas, picles, milho, ervilha;

- temperos industrializados (catchup, shoyo, molho inglês, mostarda, maionese, caldos em cubos);

- sopas desidratadas;

- manteiga com sal;

- evite carnes salgadas como carne seca, bacalhau e defumados;

- salgadinhos em pacote, amendoim salgado, biscoito picante;

- alimentos ricos em gordura, como feijoada, mocotó, rabada;

- excesso de cafeína: café, chá preto, chá mate, chocolate e refrigerantes tipo cola;

- bebidas alcoólicas.

\section{RECOMENDAÇÕES GERAIS:}

- verificar sempre a pressão arterial;

- manter o peso adequado;

- evitar o fumo;

- praticar exercícios físicos com orientação;

- evitar situações estressantes;

- dormir 08 horas diárias;

- não interromper a medicação, nem deixar de tomá-la nos horários determinados. 


\section{HIPERTRIGLICERIDEMIA}

Triglicerídios são lipídios de reserva do organismo e o aumento sérico está associado ao risco de desenvolvimento de aterosclerose e doenças coronarianas.

\section{RECOMENDAÇõES}

- consumir diariamente frutas, vegetais, folhosos, cereais integrais;

- usar adoçante com moderação ou preferir os alimentos ao natural;

- utilizar farelo de aveia, farelo de trigo, linhaça;

- consumir soja frequentemente;

- utilizar azeite de oliva extra-virgem, cru, podendo ser acrescido em pães, saladas;

- usar pescados e aves em substituição às carnes vermelhas;

- preferir alimentos cozidos, assados e grelhados.

\section{EVITAR}

- alimentos ricos em açúcar, como sorvetes, doces, bombons, tortas, refrigerantes, açúcar mascavo, mel, melaço, rapadura;

- excesso de pães e biscoitos;

- farináceos que contenham sacarose;

- massas: lasanha, pizza, macarronada;

- excesso de gorduras de origem animal, como carne de boi, bacon, rins, leite integral, embutidos;

- frituras;

- bebidas alcoólicas. 


\section{INTOLERÂNCIA À LACTOSE}

A lactose é o açúcar encontrado no leite. $\mathrm{Na}$ falta da enzima lactase, os alimentos ricos em lactose não são digeridos, provocando cólicas, edema e diarréia persistente.

\section{RECOMENDAÇõES}

- não utilizar leite de vaca;

- fazer uso do leite de soja ou isento de lactose;

- utilizar leites mistos, somente após a melhora do quadro, testando a aceitação;

- observar a composição dos alimentos preparados, como bolos, tortas, pudins, balas, temperos para salada, sopas instantâneas, misturas para bolo, verificando no rótulo, se contém leite na composição;

- permitir o uso de queijos, iogurte ou leite fermentado de acordo com a tolerância;

- consumir frutas, verduras, cereais, leguminosas, óleos vegetal. 
Insuficiência Renal Crônica é uma doença caracterizada pela redução no ritmo de filtração glomerular e alteração na habilidade do rim para excretar resíduos metabólicos.

Deve-se evitar restrições dietéticas desnecessárias, por isso a importância do acompanhamento nutricional.

\section{RECOMENDAÇÕES}

- realizar 05-06 refeições por dia;

- evitar refeições volumosas;

- seguir as orientações do nutricionista quanto à ingestão de potássio, se necessário:

- fazer cozimentos de frutas e verduras;

- evitar os seguintes alimentos: frutas e verduras frescas, chás preto e mate, café, refrigerantes;

- evitar frituras e preparações gordurosas;

- seguir as orientações do nutricionista quanto à ingestão de líquidos;

- não ingerir carambola.

\section{TRATAMENTO CONSERVADOR}

- se necessário, evitar o consumo excessivo de fontes de proteína animal e fósforo: carne bovina, aves, peixes, mariscos, ovos, leite, requeijão, queijo, iogurte, vísceras; 
- consumir alimentos como aipim, inhame;

- restringir o consumo de sal, seguindo as orientações do nutricionista;

- evitar os alimentos enlatados, embutidos e os que já contenham sal na sua composição como pães, queijos, biscoitos, salgadinhos, temperos industrializados;

- consumir moderadamente alimentos com alto teor de cálcio (leite e derivados).

\section{TRATAMENTO DIALÍTICO}

- evitar consumo de açúcar, doces, tortas, bombons. 


\section{LITÍASE RENAL}

Litíase Renal é a presença de cálculos nas vias urinárias (rins, uréteres e bexiga). A dieta, de acordo com o tipo de calculo, deve ser seguida de forma contínua, independente dos períodos de crise e das cirurgias para a retirada dos cálculos.

\section{RECOMENDAÇÕES}

- ingerir 3-4 litros de liquidos por dia;

- se possível, investigar o tipo do cálculo, para determinar o tipo de dieta;

- diminuir a ingestão de alimentos ricos em purinas como caldos de carne em tabletes, miolo, fígado, língua, rim, patê, sardinha, arenque, bacalhau carne de boi, vitela, bacon, cabrito, carneiro, truta, ovas de peixe, mexilhão, galeto, peru, porco, coelho, pato e ganso;

- evitar o uso excessivo de sal, enlatados, embutidos, temperos industrializados;

- diminuir a ingestão de alimentos ricos em ácido oxálico como beterraba cozida, cacau em pó, chocolate ao leite, germe de trigo, amendoim torrado, quiabo cozido, manjericão fresco, salsinha crua, espinafre cozido;

- consumir alimentos com alto teor de citrato: sucos de frutas ácidas (limão, laranja), chá de frutas, flores ou ervas (exceto chá preto e mate);

- evitar consumo de bebidas alcoólicas;

- não ingerir suplementos de vitamina C. 


\section{LÚPUS ERITEMATOSO SISTÊMICO}

O Lúpus Eritematoso Sistêmico (LES) é uma síndrome clínica de causa(s) desconhecida(s), caracterizada por inflamação em vários sistemas de órgãos e pela produção de auto-anticorpo que atuam na lesão tecidual imunologicamente mediada.

\section{RECOMENDAÇÕES}

- fracionar a dieta em o6 refeições ao dia;

- consumir diariamente frutas e verduras, legumes e cereais;

- preferir preparações assadas, grelhadas ou cozidas;

- preferir carnes brancas (aves e peixes), retirando a pele das aves antes das preparações;

- preferir leite desnatado;

- utilizar queijos minas, ricota, cottage;

- utilizar óleos vegetais como milho, soja, oliva, algodão, girassol;

- ingerir de 08-10 copos (200 ml) de líquidos/dia;

- reduzir o sal de adição da dieta;

- substituir pães e bolachas salgadas por pão sem sal, bolacha d'água, aipim, inhame, batata doce, banana da terra;

- usar limão, azeite doce, coentro, cebolinha, salsa hortelã, alho, cebola, pimentão, noz moscada, orégano, manjericão, alecrim, urucum, para melhorar o sabor dos alimentos;

- usar adoçante artificial. 


\section{EVITAR}

- embutidos: calabresa, salame, mortadela, presunto, salsicha;

- enlatados: peixes, azeitonas, picles;

- temperos prontos (concentrados em cubos, catchup, maionese, molho inglês, shoyo);

- sopas desidratadas;

- manteiga/margarina com sal;

- bebidas alcoólicas;

- doces, bolos, tortas, sorvetes, sobremesas açucaradas em geral. 


\section{MAL DE PARKINSON}

O Mal de Parkinson é uma doença crônica, degenerativa e progressiva que atinge os "ganglios da base" do cérebro ocasionando a falta de um neurotransmissor, a Dopamina.

\section{RECOMENDAÇÕES}

- aumentar o fracionamento da dieta em o6 refeições/dia;

- diminuir o volume das refeições;

- adequar a consistência da dieta de acordo com aceitação, podendo ser pastosa, líquida e até normal;

- ingerir bastante líquidos (chás, água, sucos);

- consumir frutas, verduras, vegetais folhosos em grande quantidade;

- se possível, utilizar alimentos laxantes: frutas com casca e bagaço (laranja, maçã, ameixa), mamão, milho, folhosos crus (agrião, acelga);

- fazer uma refeição mais concentrada em proteína à noite: leite, queijo, iogurte;

- ingerir o medicamento junto às refeições;

\section{EVITAR}

- alimentos ricos em piridoxina $\left(B_{6}\right)$, como germe de trigo, fígado, aveia;

- alimentos flatulentos como o repolho, pepino, batata doce, cebola, feijão;

- frituras e preparações gordurosas. 


\section{MEGAESÔFAGO}

O Megaesôfago é uma doença caracterizada pela dificuldade em deglutir, conseqüente a incoordenação motora da musculatura do esôfago, com dilatação e alongamento em diferentes graus.

\section{RECOMENDAÇÕES}

- a consistência deve ser de acordo com a tolerância do paciente, podendo ser branda, pastosa, semi-Ilquida ou líquida;

- enriquecer os líquidos com leite, creme de leite, leite condensado, sorvete, mel, farináceos, ovo ou suplementos nutricionais;

- fracionar a alimentação diária em no mínimo o6 vezes;

- diminuir o volume das refeições;

- mastigar bem os alimentos;

- ingerir bastante líquido (08-10 copos de $250 \mathrm{ml} / \mathrm{dia}$ );

- fazer as refeições devagar, em ambiente tranquilo;

\section{EVITAR}

- alimentos com temperaturas extremas, nem muito quente nem muito fria;

- consumo de tortas, bolos, doces;

- alimentos gordurosos, como feijoada; 


\section{RECOMENDAÇÕES GERAIS}

- manter a posição ereta depois da alimentação;

- evitar deitar-se após as refeições. 
Neoplasia é uma transformação nas células pela interação de seu DNA com substâncias químicas, radiação ou vírus, seguida de multiplicação celular, que acomete quase todos os sistemas orgânicos do corpo.

\section{OBJETIVOS}

- Melhorar a qualidade de vida do paciente que apresenta anorexia;

- Minimizar os distúrbios causados pelos tratamentos radioterápicos e/ou quimioterápicos.

\section{ORIENTAÇÕES}

- aumentar o fracionamento da dieta;

- concentrar a alimentação no período da manhã, quando o paciente se encontra com melhor disposição;

- utilizar alimentos com a consistência de melhor aceitação (líquida, semi-líquida, pastosa, normal);

- dar preferência às preparações frias;

- ingerir 10 copos de $200 \mathrm{ml}$ ou 2 litros de líquidos por dia;

- utilizar preparações com aromas fortes, bem condimentadas;

- preferir frutas cítricas;

- caso apresente lesões em boca e esôfago, evitar alimentos ácidos e condimentados; 
- usar pedaços de gelo, alimentos secos e frutas ácidas, quando apresentar náuseas;

- consumir carne de boi, peixe, frango, ovos, leite e derivados;

- usar alimentos ricos em ferro, vitamina C, cálcio e fósforo (ver em anexo);

- ingerir alimentos ricos em fibras de acordo com as orientações do nutricionista;

- usar gomas de mascar e balas sem açúcar;

\section{EVITAR}

- refeições com grandes volumes;

- alimentos muito quentes;

- frituras e alimentos excessivamente gordurosos. 
A Obesidade é uma doença metabólica crônica, caracterizada pelo acumulo excessivo de gordura corporal, suficiente para colocar a saúde sob risco.

\section{RECOMENDAÇõES}

- fracionar as refeições em 05 a 06 vezes por dia;

- diminuir o volume das refeições;

- mastigar bem os alimentos;

- realizar as refeições a mesa, em ambientes calmos;

- não substituir uma refeição por lanches rápidos;

- não omitir refeições;

- manter alimentação saudável durante os fins de semana;

- iniciar as principais refeições, com uma salada crua de vegetais folhosos como alface, repolho, agrião, acelga, tomate, pepino ou vegetais cozidos;

- usar alimentos integrais de preferência;

- utilizar frutas com bagaço e casca quando possível;

- fazer uso do leite desnatado;

- preferir preparações cozidas, assadas ou grelhadas;

- utilizar adoçante artificial em quantidades mínimas, preferindo sentir o sabor natural dos alimentos;

- fazer uso moderado de óleos vegetais (soja, oliva, miIho) nas preparações;

- evitar ingerir líquidos em excesso (no máximo 200ml), durante as refeições principais (almoço e jantar); 
- ingerir 2 litros de água filtrada ou fervida por dia;

\section{PREFERIR}

\section{Hortaliças}

Acelga, agrião, alface, berinjela, couve, pepino, repolho, tomate, abóbora, beterraba, pimentão, quiabo, vagem, etc. Ingeri-las cruas, cozidas, grelhadas ou em forma de saladas. Temperá-las com vinagre ou limão e azeite de oliva extravirgem.

\section{Frutas}

Melancia, abacaxi, melão, tangerina, laranja, lima, umbu, carambola, maçã, etc.

Substituir os sucos pelas frutas.

Utilizar frutas ou gelatinas nos lanches e sobremesa.

\section{Leguminosas}

Feijão, grão-de-bico, lentilha, ervilha, feijão verde etc.

\section{Cereais}

O uso de arroz deve ser moderado.

Este (arroz) pode ser substituído por macarrão ou batata na mesma quantidade.

\section{Leite e derivados}

Dar preferência ao leite desnatado.

Utilizar queijos com baixo teor de gordura (Minas Frescal, Ricota, Cottage).

\section{Carnes}

Frango, peru, pescados, retirando a pele antes da cocção. 
O uso da carne bovina deve ser restringindo a 02 vezes por semana.

As preparações devem ser assadas, grelhadas ou cozidas.

\section{Ovos}

Preferir clara cozida ou pochê.

Ovo inteiro cozido ou pochê, no máximo 02 vezes por semana.

\section{EVITAR}

- jejuns forçados;

- dietas "milagrosas";

- uso de medicação sem orientação;

- bebidas alcoólicas;

- refrigerantes;

- alimentos com alto valor calórico, como: biscoitos recheados, bombons, doces, salgadinhos, tortas, sorvetes, açúcar, mel, rapadura, melaço;

- macarronada com molho, pizza, lasanha;

- frituras;

- alimentos excessivamente gordurosos, como sarapatel, feijoada, mocotó, dobradinha, sarapatel, cozido, acarajé, abará, vatapá, caruru;

- preparações com leite de coco e dendê;

- carnes salgadas e defumadas no feijão;

- embutidos, como: salame, presunto, salsicha, calabresa;

- enlatados, como: sardinha, patê, quitute;

- condimentos, como maionese, catchup, mostarda e molhos concentrados em sal;

- alimentos achocolatados;

- manteiga ou margarina. 


\section{OBSTIPAÇÃO}

Obstipação (prisão de ventre) é uma modificação do ritmo intestinal, mais especificamente do intestino grosso, caracterizada pela redução número de evacuações, com fezes endurecidas e ressecadas e esforço à defecação.

\section{RECOMENDAÇÕES}

- ingerir diariamente alimentos ricos em fibras;

- consumir bastantes frutas, utilizando o bagaço e casca quando possível;

- preferir à fruta aos sucos;

- utilizar as frutas nas sobremesas e lanches;

- ingerir verduras de preferência cruas;

- usar de preferência os alimentos integrais, principalmente o pão e o arroz;

- usar farelo de aveia em qualquer refeição, inicialmente or colher de chá e aumentar gradualmente, segundo orientações do Nutricionista, até alcançar de 03 colheres de sopa por dia;

- beber bastante líquidos no intervalo das refeições, o8 a 10 copos (200 ml) por dia;

- beber or copo (200 ml) de água gelada simples ou com ameixa em jejum;

- mastigar bem os alimentos antes de ingeri-los;

- fracionar a alimentação diária de 05 a 06 vezes, estabelecendo horário para cada refeição; 


\section{EVITAR}

- evitar alimentos obstipantes, como: banana-da-prata, maçã sem casca, caju, goiaba, maisena, farinha de mandioca, creme de arroz, limonada;

- evitar alimentos refinados como farinhas, massas e alimentos industrializados;

- evitar beber líquidos durante as refeições.

\section{RECOMENDAÇÕES GERAIS}

- realizar exercício físico diário;

- cultivar o hábito de ir ao banheiro no mesmo horário, mesmo que não tenha vontade de defecar;

- evitar o uso regular de laxativos.

\section{Use freqüentemente alimentos laxantes}

\begin{tabular}{l|l} 
Abacate & logurte com ameixa \\
Abóbora & Laranja c/ o bagaço \\
Aipim & Mamão \\
Ameixa & Maxixe \\
Ando & Milho \\
Arroz integral & Pão integral \\
Caqui & Quiabo \\
Cajá & Tangerina com bagaço \\
Ervilha & Todos folhosos \\
Feijão & Umbu \\
Gérmen de trigo & Uva \\
Granola & Vagem \\
Kiwi &
\end{tabular}




\section{Exemplos de coquetéis laxantes}

I. Bater no liquidificador e não coar:

01 fatia de mamão

o6 ameixas secas

$200 \mathrm{ml}$ de suco de laranja (sem água e sem coar)

01 colher sopa de creme de leite light ou azeite de oliva

II. 20oml de suco de laranja (sem água e sem coar)

$1 / 2$ fatia de mamão

01 rodela de abacaxi

01 fatia de melancia com caroço

No caso de hemorróidas, seguir as mesmas orientações para obstipação. 
A Osteoporose é uma é uma doença óssea metabólica, caracterizada por desmineralização e redução da matriz óssea.

\section{RECOMENDAÇõES}

- para prevenção, consumir alimentos com alto teor em cálcio:

Folhas verdes escuras (agrião, espinafre)

Leite e derivados

Gema de ovo, mariscos

Sardinha fresca

Leguminosas (feijão, ervilha)

- consumir alimentos com alto teor em vitamina D:

Gema de ovo

Queijo prato

Manteiga

Salmão

Óleo de fígado de peixe e de bacalhau

- consumir alimentos fontes de magnésio e vitamina K: frutas e verduras;

\section{EVITAR}

- ingestão de bebidas alcoólicas;

- alimentos ricos em cafeína, como café, chá mate, chocolate, refrigerantes a base de cola; 
- excesso de alimentos protéicos: carne de boi, frango, peixes.

\section{RECOMENDAÇÕES GERAIS:}

- tomar banho de sol até $10 \mathrm{~h}$ da manhã ou após $16 \mathrm{~h}$ da tarde;

- praticar exercício físico regularmente;

- evitar o fumo. 
A Pancreatite é uma inflamação do pâncreas caracterizada por edema, exsudato celular e necrose gordurosa, podendo ser aguda ou crônica. Na pancreatite crônica a inflamação não cede ou há recidivas freqüentes.

\section{RECOMENDAÇÕES}

- proibida a ingestão de bebidas alcoólicas;

- ingerir alimentos que sejam boas fontes de TCM, como a polpa e óleo de coco;

- realizar 05 a 06 pequenas refeições por dia;

- consumir frutas, verduras, legumes, cereais e leguminosas;

- ingerir alimentos com alto teor de vitamina B12, como fígado, leite, ovos, peixe, queijo e carnes;

- preferir carnes brancas de aves e peixes, retirando a pele antes das preparações;

- utilizar preparações cozidas, grelhadas ou assadas;

- consumir leite desnatado e queijos cottage, minas ou ricota;

- ingerir no mínimo 02 litros de líquidos (água, chá, suco) por dia;

\section{EVITAR}

- grandes volumes alimentar;

- ingestão de preparações gordurosas como feijoada, moquecas, churrasco, sarapatel; 
- frituras;

- excesso de óleos, manteiga/margarina;

- creme de leite, maionese, requeijão;

- salgadinhos, batata frita;

- usar alimentos contendo açúcar: balas, bolo, doces, chocolates, refrigerantes, mel, rapadura;

- consumir farinha de mandioca, maisena, creme de arroz; preferir farináceos de tapioca, fubá de milho ou aveia. 


\section{ÚLCERA PÉPTICA}

A Úlcera Péptica é uma doença multifatorial resultante da interação de fatores genéticos e ambientais representados pela presença da bactéria Helicobacter pylori.

\section{RECOMENDAÇÕES}

- fracionar as refeições de 06 a 07 vezes ao dia;

- reduzir o volume das refeições;

- realizar as refeições com tranqüilidade;

- mastigar bastante os alimentos;

- usar diariamente vegetais em geral;

- consumir frutas ácidas, evitando apenas as que lhe causem desconforto;

- temperar os alimentos, evitando condimentos picantes como picles, pimenta preta, cominho, catchup, mostarda;

- utilizar leite desnatado e queijos minas, cottage ou ricota;

- consumir o leite em quantidade moderada, em média or copo por dia;

- preferir as preparações cozidas, assadas, grelhadas;

- fazer a última refeição com intervalo de no mínimo uma hora antes de dormir;

- ingerir no mínimo o2 litros de líquidos por dia;

\section{EVITAR}

- alimentos enlatados e conservas;

- frituras; 
- preparações gordurosas;

- alimentos que causam desconfortos gástricos;

- alimentos que produzam gases, como repolho, milho, cebola;

- períodos de jejum ou excesso de alimentação;

- beber líquidos em excesso às principais refeições;

- bebidas alcoólicas;

- bebidas gasosas como refrigerantes, água com gás;

- alimentos ricos em cafeína como café, chocolate, chá mate, chá preto;

- alimentos muito gelados ou muito quentes; 

ANEXOS 



\section{ALIMENTOS FLATULENTOS}

\begin{tabular}{l|l|l} 
Abacate & Acelga & Açúcar \\
Agrião & Águas gasosas & Alho \\
Amêndoa & Amendoim & Batata doce \\
Beterraba & Brócolis & Castanha \\
Cebola & Cebolinha & Cerveja \\
Coalhada & Couve & Couve-flor \\
Chucrute & Doces & Feijão seco \\
Fava & Gérmen de trigo & Grão de bico \\
logurte & Jaca & Leite \\
Lentilha & Maçã crua & Melão \\
Melancia & Mostarda & Milho \\
Nabo & Nozes & Ovo \\
Pepino & Pimentão & Pimentas \\
Rabanete & Refrigerante & Repolho \\
Soja & Sorvete & Uva Passas \\
Rager &
\end{tabular}

Vagem 


\begin{tabular}{l|l} 
Abóbora & Alho \\
Azeite de oliva & Cenoura \\
Cereais integrais & Couve \\
Brócolis & Damasco \\
Espinafre & Feijão \\
Frutos do mar & Inhame \\
logurte & Leite fermentado \\
Linhaça & Maçã \\
Mamão & Manga \\
Melancia & Óleos vegetais \\
Peixe & Soja \\
Tomate & Uva \\
Vinho &
\end{tabular}




\section{ALIMENTOS LAXANTES}

\begin{tabular}{l|l|l} 
Abacate & Abacaxi & Abóbora \\
Ameixanha & Agrião & Amendoim \\
Beterraba & Arroz integral & Aspargo \\
Couve & Creme de leite & Cenoura crua \\
Farelos de cereais & Fruthas com bagaço \\
Figo seco & Feijão \\
Kiwi & Lentilha & Grão de bico \\
Mamão & Manga & Maçã c/ casca \\
Mel, melado & Melão & Maxixe \\
Morango & Nozes & Milho \\
Quiabo & Pão Integral & Óleos vegetais \\
Rabanete & Repolho & Pepino \\
Vagem & Tomate & Uva passa
\end{tabular}


Água de arroz

Banana da prata

Caju

Cenoura cozida

Chá preto

Farinha de araruta

Farinha de trigo

Limão

Maizena

Mucilagem de arroz

Pêra sem casca

Torradas
Arroz branco

Batata

Cará

Chá broto da goiaba

Creme de arroz

Farinha de mandioca

Goiaba

Maçã sem casca

Mandioca

Pão branco

Tapioca 


\section{ALIMENTOS COM ALTO TEOR DE ÁCIDO FÓLICO}

\begin{tabular}{|l|l|l} 
Abacate & Abacaxi & Agrião \\
Aveia & Amendoim & Aspargo \\
Carne magra & Banana & Brócolis \\
Cogumelo & Couve & Centeio \\
Ervilha & Espinafre & Couve-flor \\
Fígado & Gema de ovo & Iogurte \\
Laranja & Lentilha & Limão \\
Morango & Pão integral & Peixe \\
Pêssego & Queijos & Tangerina
\end{tabular}




\section{ALIMENTOS COM ALTO TEOR DE ÁCIDO OXÁLICO}

\begin{tabular}{|l|l|l} 
Abóbora & Acelga & Agrião \\
Amendoim & Alho-poró & Amêndoas \\
Bebidas fermentadas & Amora & Batata doce \\
Cacau & Casca de laranja & Casca de lima \\
Casca limão & Castanha de caju & Cebolinha \\
Chá preto & Chicória & Chocolate \\
Couve & Escarola & Espinafre \\
Feijão & Framboesa & Gérmen de trigo \\
Milho branco & Marmelada & Morangos \\
Mostarda verde & Nozes & Pimenta verde \\
Passas vermelhas & Quiabo & Repolho crespo \\
Ruibarbo & Salsa & Sopa de tomate \\
Sopa de vegetais & Tangerina & Uvas rosadas \\
&
\end{tabular}




\section{ALIMENTOS COM ALTO TEOR DE CÁlCIO}

Abobrinha

Alfafa

Anchovas

Beterraba

Chocolate ao leite

Corvina

Creme de leite

Farinha de peixe

Espinafre

logurte desnatado

Marisco

Mingau

Queijo Parmesão

Queijo Prato

Rabanete

Ricota

Sementes de girassol

Tofu
Agrião

Amêndoa

Badejo

Brócolis

Coalhada

Couve

Doce de leite

Feijão branco

logurte

Leite desnatado

Merluza

Gema de ovo

Queijo Minas

Quiabo

Requeijão

Salmão

Sardinha em conserva 


\section{ALIMENTOS COM ALTO TEOR DE COLESTEROL}

\begin{tabular}{l|l} 
Achocolatados & Bacon \\
Banha & Bolachas recheadas \\
Caranguejo & Caldo de carne \\
Camarão & Creme de leite \\
Coração & Gema de ovo \\
Fígado & Lagosta \\
logurte integral & Maionese \\
Leite Integral & Miolo \\
Manteiga & Ostra \\
Molhos industrializados & Presunto \\
Pele de aves & Queijo minas integral \\
Queijos amarelos & Rim \\
Requeijão & Sardinha em conserva \\
Salsicha & Tortas \\
Sorvete &
\end{tabular}




\section{ALIMENTOS COM ALTO TEOR DE ENXOFRE}

\begin{tabular}{l|l} 
Acelga & Agrião \\
Aipo & Brócolis \\
Caruru & Chicória \\
Carne & Couve \\
Couve-flor & Cebola \\
Escarola & Espinafre \\
Feijão-preto & Grão de bico \\
Leite Milho & Mostarda \\
Nabo & Pimentão \\
Rabanete & Repolho \\
Ovo &
\end{tabular}




\begin{tabular}{|l|l|l} 
Açaí & Açúcar mascavo & Agrião \\
Baneixa seca & Amêndoa & Aveia \\
Brócolis & Carne & Beterraba \\
Couve & Damasco & Castanha de caju \\
Espinafre & Melado & Ervilha \\
Fígado & Gema de ovo & Inhames \\
Jenipapo & Jiló & Lentilha \\
Maçã & Marisco & Morango \\
Mostarda & Nozes & Ostra \\
Pão integral & Pêra & Pólen \\
Quiabo & Rabanete & Rapadura \\
Repolho & Rim & Salsa \\
Sardinha & Sementes de abóbora & Sementes de gergelim \\
Uva passa & Sementes de girassol & Tâmara \\
\hline
\end{tabular}




\section{ALIMENTOS COM ALTO TEOR DE FIBRAS}

\begin{tabular}{|l|l|l} 
Abóbora & Acelga & Alcachofra \\
Amrião & Ameixa & Amêndoas \\
Aveia & Amora preta & Arroz integral \\
Beterraba & Avelã & Banana \\
Castanhas secas & Cenoura & Brócolis \\
Couve & Couve-flor & Coco secois matinais \\
Damasco & Ervilha & Espinafre \\
Farinha de arroz & Farelo de aveia & Farelo de trigo \\
Feijões & Figo seco & Framboesa \\
Germe de trigo & Goiaba & Grão de bico \\
Jaca & Jenipapo & Laranja \\
Lentilha & Linhaça & Maçã \\
Milho & Nozes & Pão integral \\
Pêra seca & Semolho \\
Soja & Sementes de gergelim \\
\hline
\end{tabular}




\section{ALIMENTOS COM ALTO TEOR DE FÓSFORO}

\begin{tabular}{l|l|l} 
Amêndoas & Amendoim & Anchova \\
Arenque & Aveia & Avelãs \\
Bacalhau & Cacau em pó & Café solúvel \\
Camarão & Carnes & Castanhas \\
Centeio & Cereais & Chás \\
Corvina & Couve & Ervilha seca \\
Farinha de aveia & Farinha de peixe & Farinha soja \\
Farelo de trigo & Feijões & Fígado \\
Frango & Gema de ovo & Germe trigo Leite \\
Lentilha & Nozes & Ovas de peixe \\
Pão integral & Peixes & Sementes de abóbora \\
Queijo & Requeijão & Semente de girassol \\
Tofu &
\end{tabular}




\section{ALIMENTOS COM ALTO TEOR DE POTÁSSIO}

\begin{tabular}{|l|l|l} 
Abacate & Abacaxi & Acelga \\
Aipo & Almeirão & Ameixa \\
Aveia & Amendoim & Amora \\
Banana d'água & Avelã & Banana prata \\
Beterraba & Brócolis & Batata doce \\
Caldo de carne & Castanha & Cacau \\
Chá preto & Chicória & Chocolate \\
Couve & Couve-flor & Camarão seco \\
Damasco & Ervilha & Espinafre \\
Feijão & Figos & Frutas secas \\
Grão de bico & Laranja & Lentilha \\
Lima & Mamão & Mandioca \\
Mandioquinha & Maracujá & Melancia \\
Melão & Milho verde & Nozes \\
Palmito & Pão integral & Rabanete \\
Soja & Tomate \\
Uva passa & Marindo & \\
\hline
\end{tabular}




\section{ALIMENTOS COM ALTO TEOR DE SÓdio}

\begin{tabular}{|l|l|l} 
Atum enlatado & Aspargo & Azeitona verde \\
Bacalhau & Bacon & Batata frita \\
Biscoito salgado & Caldos concentrados & Carne do sol \\
Charque & Chouriço & Ervilha enlatada \\
Extrato de tomate & Ketchup & Lingüiça \\
Manteiga c/ sal & Margarina c/ sal & Milho enlatado \\
Molho inglês & Mortadela & Mostarda \\
Paio & Presunto & Queijos \\
Salame & Salsicha & Salgadinhos \\
Sardinha enlatada & Shoyu & Sopas prontas \\
Palmito em conserva & Patês industrializados & Picles \\
Presunto & Requeijão & Temperos industrializados
\end{tabular}

Toucinho 


\section{ALIMENTOS COM ALTO TEOR DE VITAMINAS ANTIOXIDANTES}

As Vitaminas Antioxidantes são: vitamina E, Beta-caroteno e vitamina C. A função dentro do organismo é neutralizar moléculas potencialmente nocivas, chamadas "radicais livres", produzidas por processos como digestão ou respiração.

BETA-CAROTENO
\begin{tabular}{|l|l|l} 
Abóbora & Açafrão & Batata doce \\
Brócolis & Cenoura & Couve \\
Damasco seco & Espinafre & Fígado \\
Mamão & Manga & Melão \\
Ovo & Pimentão amarelo & Pimentão vermelho \\
Pêssego &
\end{tabular}

VITAMINA C

Abacaxi
Brócolis
Escarola
Kiwi
Manga
Pimentão
Umbu

Acerola

Caju

Espinafre

Laranja

Melão

Repolho
Agrião

Couve

Goiaba

Limão

Morango

Tomate 


\section{VITAMINA E}

\begin{tabular}{|l|l|l} 
Abacate & Amêndoas & Avelãs \\
Castanhas & Cereais integrais & Gema de ovo \\
Gérmen de trigo & Leite & Nozes \\
Óleos vegetais & Vegetais folhosos &
\end{tabular}




\section{ALIMENTOS COM ALTO TEOR DE GORDURAS TRANS}

Batata frita

Biscoito recheado

Caldos de carne em cubos

Margarinas

Sorvete

Produtos confeitaria

e panificação
Biscoito cream craker

Bolos industrializados

Folhados

Salgadinhos industrializados

Tortas 


\section{TABELA ÍNDICE GLICÊMICO}

\begin{tabular}{|c|c|c|c|}
\hline Alimento & IG & Alimento & IG \\
\hline Amendoim & 21 & Aveia & 78 \\
\hline Feijão de soja & 23 & Arroz integral & 79 \\
\hline logurte sem sacarose & 27 & Pipoca & 79 \\
\hline Frutose & 32 & Musli & 80 \\
\hline Lentilhas & 38 & Manga & 80 \\
\hline Leite integral & 39 & Arroz branco & 81 \\
\hline Feijão manteiga & 44 & Banana & 83 \\
\hline Damasco seco & 44 & Sopa de feijão & 84 \\
\hline Leite desnatado & 46 & Mingau de aveia & 87 \\
\hline logurte com sacarose & 48 & Chocolate & 84 \\
\hline Maçã & 52 & Sorvete & 84 \\
\hline Sopa de tomate & 54 & Sacarose & 87 \\
\hline Pêra & 54 & Bolos & 87 \\
\hline Suco de maçã & 58 & Biscoitos & 90 \\
\hline Spaguete & 59 & Cuscuz & 93 \\
\hline All Bran & 60 & Milho & 98 \\
\hline Laranja & 62 & Crackers & 99 \\
\hline Lactose & 65 & Farinha de trigo & 99 \\
\hline Pêssego enlatado & 67 & Pão branco & 101 \\
\hline Pêssego enlatado & 67 & Mel & 104 \\
\hline Arroz parbolizado & 68 & Trigo cozido & 105 \\
\hline Ervilhas & 68 & Batata frita & 107 \\
\hline Feijão cozido & 69 & Tapioca & 115 \\
\hline Inhame & 73 & Corn Flakes & 119 \\
\hline Suco de laranja & 74 & Batata cozida & 121 \\
\hline$\underline{\text { Kiwi }}$ & 75 & Glicose & 138 \\
\hline Batata doce & 77 & & \\
\hline
\end{tabular}


REFERÊNCIAS 

AACE Diabetes Mellitus Clinical Practice Guidelines Task Force. American Association of Clinical Endocrinologists medical guidelines for clinical practice for the management of diabetes mellitus. Endocr Pract. 2007;13 Suppl 1:1-68.

ANDERSON L. Nutrição. 17 ed. Rio de Janeiro: Guanabara, 1998.

ANGELIS RC. New concepts in nutrition: considerations on the connection diet-health. Arq Gastroenterol 2001; 38(4):269-271.

ALVARENGA M, LARINO MA. Terapia nutricional na anorexia e bulimia nervosas. Rev Bras Psiquiatr 2002;24(Supl III):39-43.

ARANHA FQ, BARROS ZF, MOURA LSA, GONÇALVES MCR, BARROS JC, METRI JC, SOUZA MS. O papel da vitamina $C$ sobre as alterações orgânicas no idoso. Rev. Nutr., 2000; 13(2):89-97.

CALDAS CP. Saúde do idoso. Rio de Janeiro: Eduerj, 1998.

CARDOSO MA, PENTEADO MVC. Intervenções nutricionais na anemia ferropriva. Cad. Saúde Pública 1994; 10(2):231-240.

CHAMPAGNE CM. Dietary interventions on blood pressure: the Dietary Approaches to Stop Hypertension (DASH) trials. Nutr Rev. 2006;64(2):S53-6.

COSMAN F. The prevention and treatment of osteoporosis: a review. Med Gen Med. 2005;7(2):73. 
CUPPARI L. Nutrição clínica no adulto - Guia de medicina ambulatorial e hospitalar (UNIFESP/Escola Paulista de Medicina). 1 ed. São Paulo: Manole, 2002.

DOUGLAS CR. Tratado de Fisiologia Aplicado à Nutrição. Ed São Paulo: Robe, 2002.

DUNKER KLL, PHILIPPI ST. Hábitos e comportamentos alimentares de adolescentes com sintomas de anorexia nervosa. Rev Nutr 2003; 16(1): 51-60.

ESTEVES EA, MONTEIRO JBR. Efeitos benéficos das isoflavonas de soja em doencas crônicas. Rev. Nutr. 2001;14(1):43-52.

FISBERG M. Obesidade na infância e adolescência. São Paulo: Fundação BYK, 1995.

FLEK J, CALEGARO MIC. Importância do índice glicêmico para pacientes com diabetes mellitus. Rev Bras Nutr Clin 2005;20(2): 95-100.

FLORA APL, DICHI I. Aspectos atuais na terapia nutricional da doença inflamatória intestinal. Rev Bras Nutr Clin 2006; 21 (2):131-7.

FOX M, BARR C, NOLAN S, LOMER M, ANGGIANSAH A, WONG T. The effects of dietary fat and calorie density on esophageal acid exposure and reflux symptoms. Clin Gastroenterol Hepatol. 2007;5(4):439-44.

FRANCO G. Tabela de composição química dos alimentos. 9 ed. Rio de Janeiro: Atheneu, 2000.

HILL ID, DIRKS MH, LIPTAK GS, COLLERRI RB et al. Guideline for the diagnosis and treatment of celiac disease in children: recommendations 
of the North American Society for Pediatric Gastroenterology, Hepatology and Nutrition.J Pediatr Gastroenterol Nutr. 2005;40(1):1-19.

http://www.abeso.org.br acessado em 15/03/2007

http://www.acelbra.org.br acessado em 24/03/2007

http://www.epilepsia.org.br acessado em 20/01/2007

http://www.sbaf.org.br/SBAF/

http://www.stanford.edu/group/ketodiet acessado em 20/01/2007

JUZWIAK CR, PASCHOAL VCP, LOPEZ FA. Nutrição e atividade física. J. pediatr. 2000;76(S3):S349-S358.

KITCHIN B, MORGAN SL. Not just calcium and vitamin D: other nutritional considerations in osteoporosis. Curr Rheumatol Rep. 2007;9(1):85-92.

LEITE S, ARRUDA S, LINS R, FARIA OP. Nutrição e cirurgia bariátrica. Rev Bras Nutr Clin 2003; 18(4):183-9.

MAHAN K., ARLIN M. Krause: alimentação, nutrição e dietoterapia. 10 ed. São Paulo: Roca, 2002.

NÓBREGA FJ. Distúrbios da nutrição. Rio de Janeiro: Revinter, 1998.

OLIVEIRA D. Ciências nutricionais. 1 ed. São Paulo: Sarvier, 2000.

OLIVEIRA ECM, FREITAS CLCF, TEODÓSIO MR. Nutrientes, líquidos e 
fibras na formação de cálculos renais. Rev Bras Nutr Clin 2003; 18(3): 142-148.

OMS. Manual de necessidades nutricionais humanas. 1 ed. São Paulo: Atheneu, 2003.

PARVEZ S, MALIK KA, AH KANG S, KIM HY. Probiotics and their fermented food products are beneficial for health. J Appl Microbiol. 2006;100(6):1171-85.

PINHEIRO AB. Tabela para avaliação de consumo alimentar em medidas caseiras. 2 ed. Rio de Janeiro: 1994.

PRENTICE A, SCHOENMAKERS I, LASKEY MA, DE BONO S, GINTY F, GOLDBERG GR. Nutrition and bone growth and development. Proc Nutr Soc. $2006 ; 65(4): 348-60$.

IV Diretriz Brasileira Sobre Dislipidemias e Prevenção da Aterosclerose Departamento de Aterosclerose da Sociedade Brasileira de Cardiologia. Arq Bras Cardiol. 2007; 88(SI):2-19.

V Diretrizes Brasileiras de Hipertensão. http://www.sbh.org.br/documentos/index.asp acessado em 20/03/2007.

RIELLA, M.C; MARTINS, C. Nutrição e o Rim. $1^{\circ}$ ed. Rio de Janeiro: Gunabara, 2001.

SANTOS RR, COTRIM HP. Relevância das medidas antropométricas na avaliação de pacientes com doença hepática gordurosa não alcoólica. Rev Bras Nutr Clin 2006; 21(3):229-32. 
SHAH A, URIBE J, KATZ PO. Gastroesophageal reflux disease and obesity. Gastroenterol Clin North Am. 2005;34(1):35-43.

SILAMI-GARCIA E, RODRIGUES LOC, FARIA MHS, ARAÚJO-FERREIRA AP, NASSIF-LEONEL C, OLIVEIRA MC, SAKURAI E, STRADIOTO MA, CANÇADO GHCP. Efeitos de carboidratos e eletrólitos sobre a termorregulação e a potência anaeróbia medida após um exercício prolongado no calor. Rev. bras. Educ. Fís. Esp. 2004;18(2):179-89.

SOLÁ EJ. Manual de dietoterapia do adulto. 7 ed. São Paulo: Atheneu, 2002. TAKEY M, EISENSTEIN E. Abordagem de adolescentes com anorexia nervosa: relato de caso. Rev Bras Nutr Clin 2006; 21 (2):174-7.

WAITZBER, D.L. Nutrição oral, enteral e parenteral. $3^{\text {a }}$ ed. São Paulo: Atheneu. 2004.

WHO/FAO/ONU. Necessidades de energia e proteína. 1 ed. São Paulo: Roca, 1998.

YUAN G, AL-SHALI KZ, HEGELE RA. Hypertriglyceridemia: its etiology, effects and treatment. CMAJ. 2007;176(8):1113-20. 

Este livro foi publicado

no formato $150 \times 210 \mathrm{~mm}$

Miolo em papel $75 \mathrm{~g} / \mathrm{m}^{2}$

Tiragem 500 exemplares

Impresso no setor de Reprografia da EDUFBA

Impressão de capa e acabamento: Cartograf 